\title{
Potential role of increased oxygenation in altering perinatal adrenal steroidogenesis
}

\author{
Vishal Agrawal', Meng Kian Tee', Jie Qiao', Marcus O. Muench ${ }^{2,3}$ and Walter L. Miller ${ }^{1}$
}

BACKGROUND: At birth, the large fetal adrenal involutes rapidly, and the patterns of steroidogenesis change dramatically; the event(s) triggering these changes remain largely unexplored. Fetal abdominal viscera receive hypoxic blood having a partial pressure of oxygen of only $\sim 2 \mathrm{kPa}(20-23 \mathrm{~mm} \mathrm{Hg})$; perinatal circulatory changes change this to adult values ( $20 \mathrm{kPa})$. We hypothesized that transition from fetal hypoxia to postnatal normoxia participates in altering perinatal steroidogenesis. METHODS: We grew midgestation human fetal adrenal cells and human NCl-H295A adrenocortical carcinoma cells in $2 \%$ $\mathrm{O}_{2}$, then transitioned them to $20 \% \mathrm{O}_{2}$ and quantitated steroidogenic mRNAs by quantitative PCR and microarrays.

RESULTS: Transitioning fetal adrenal cells from hypoxia to normoxia increased mRNAs for $17 \alpha$-hydroxylase/17,20 lyase

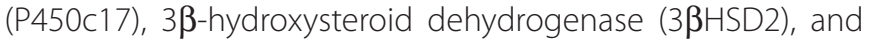
steroidogenic acute regulatory protein (StAR). We repeated the protocol with $\mathrm{NCl}-\mathrm{H} 295 \mathrm{~A}$ cells acclimated to hypoxia for $15 \mathrm{~d}$, quantitating 31,255 transcripts by microarray. Using an arbitrary 1.5-fold difference, $1 \mathrm{~d}$ of normoxia increased 4 transcripts and decreased 56 , whereas $2 \mathrm{~d}$ of normoxia increased 62 transcripts and decreased 105. P450c17, 3ßHSD2, and StAR were ranked among the top eight increased transcripts.

CONCLUSION: These data suggest that the hypoxic/normoxic transition at birth contributes to perinatal changes in adrenal steroidogenesis.

A $\mathrm{t}$ birth, the transition from intrauterine to extrauterine life requires major endocrine adjustments, such as the metabolic adjustments following the discontinuation of glucose supplied from cord blood and the rapid shift from producing reverse T3 to T3. Understanding these transitions is essential in the endocrine care of the perinatal patient. Evaluation of newborn adrenal function is complicated by the fact that the fetal and later infant adrenals are very different. The human fetal adrenal has two zones, fetal and definitive, in contrast to the three zones, glomerulosa, fasciculata, and reticularis, of the adult gland. Fetal adrenal steroidogenesis begins at about 7 wk gestation: steroidogenic enzymes are detectable by immunocytochemistry in the fetal zone at 50-52 d postconception, and primary cultures of the $8 \mathrm{wk}$ adrenal produce cortisol and respond to adrenocorticotropic hormone (1). The fetal adrenal transiently expresses $3 \beta$-hydroxysteroid dehydrogenase, type 2 (3ßHSD2, encoded by HSD3B2) at about $8-10 \mathrm{wk}$, permitting fetal adrenal cortisol synthesis at the same time when male genital development occurs, thus helping to prevent the virilization of female fetuses by suppressing fetal adrenal androgen synthesis (1). The fetal adrenal has relatively little 3ßHSD2 activity after $12 \mathrm{wk}(1,2)$ but has $17 \alpha$-hydroxylase and robust 17,20 lyase activity (both catalyzed by cytochrome P450c17, encoded by CYP17A1), considerable sulfotransferase activity, and little steroid sulfatase activity accounting for its abundant production of dehydroepiandrosterone (DHEA) and its sulfate (DHEAS). DHEAS is secreted, 16a-hydroxylated in the fetal liver by CYP3A7 (3-5), and then acted on by placental $3 \beta \mathrm{HSD} 1,17 \beta \mathrm{HSD} 1$ (17 $\beta$-hydroxysteroid dehydrogenase type 1, encoded by HSD17B1), and aromatase (P450aro, encoded by CYP19A1) to produce estriol $(6,7)$. Fetal adrenal steroids are the source of about half of the estrone and estradiol and $90 \%$ of the estriol in the maternal circulation (8). Despite the large amounts of DHEA and DHEAS produced by the fetal adrenal and their consequent metabolism to estrogens by the placenta, evidence for an essential role for these steroids is scant, as fetuses with genetic disorders of adrenal steroidogenesis develop normally, reach term gestation, and undergo normal parturition (9). Although glucocorticoids can induce premature lung maturation, they do not appear to be needed when human gestation goes to term, as complete absence of the glucocorticoid receptor is compatible with normal term birth and pulmonary function (10).

It has long been known that the adrenal grows rapidly throughout fetal life, reaching a combined weight of $8-9 \mathrm{~g}$ at birth (equal to the combined weight of the adult adrenals) (11-13), but within weeks of birth, the fetal adrenals involute to a total weight of about $2 \mathrm{~g}(12,14)$. This change is mediated by apoptosis of the fetal zone, possibly in response to activin $A$ or transforming growth factor- $\beta$ (15). In parallel with the involution of the fetal zone of the adrenal, secretion of DHEA and DHEAS falls dramatically (16-18). The triggering mechanism for this rapid, profound change in adrenal morphology, cellular architecture, and steroidogenesis is not known. It has been suggested that the involution of the fetal adrenal is more related to gestational age than to timing 
after birth (19), but more recent studies indicate that parturition itself triggers fetal adrenal involution, which was interpreted as suggesting that the withdrawal of a placental factor stimulated the onset of fetal adrenal apoptosis (20). We hypothesize that the transition from intrauterine hypoxia to extrauterine normoxia is also a key event in triggering the remodeling of the fetal adrenal. Human fetal abdominal viscera receive hypoxic blood having a partial pressure of oxygen $\left(\mathrm{Po}_{2}\right)$ of only $2 \mathrm{kPa}(1 \mathrm{kPa}=7.5 \mathrm{Torr}$; 1 Torr $=1 \mathrm{~mm} \mathrm{Hg}$ ); perinatal circulatory changes change this to adult values of $\sim 20 \mathrm{kPa}$. As parturition itself appears to trigger the changes in fetal adrenal steroidogenesis and architecture, we considered whether the perinatal change in arterial oxygen tension participates in these changes. As a preliminary test of this hypothesis, we grew adrenal cells in long-term hypoxic conditions designed to mimic the intrauterine environment and then examined changes in gene expression upon transition to a normoxic environment that models extrauterine life.

\section{RESULTS}

\section{Human Fetal Adrenal Cells}

To study the changes in the human adrenal as it transitions from the hypoxia of fetal life to the normoxia of the extrauterine newborn environment, we first incubated adrenal cells from a single 17-wk human fetus under hypoxic conditions for $1 \mathrm{~d}$, followed by normoxic conditions for 1 or $2 \mathrm{~d}$. Total cellular RNA from these cells was hybridized to Illumina BeadChip microarrays for gene expression analyses. Using an arbitrary cutoff of $>1.5$-fold change for gene activation or $<0.67$-fold change for gene repression, the mRNAs encoded by 107 genes were increased, and those for 114 genes were decreased when the cells were shifted from fetal hypoxic conditions to normoxic conditions for $1 \mathrm{~d}$, and 179 mRNAs were increased and 296 genes were decreased after $2 \mathrm{~d}$ in normoxic conditions (Supplementary Tables S1

a Total number of genes activated or inhibited in fetal adrenal cells in normoxia over control in hypoxia:

$1 \mathrm{~d}$ normoxia, 221 genes $(107 \uparrow+114 \downarrow)$

2 d normoxia, 475 genes $(179 \uparrow+296 \downarrow)$

b

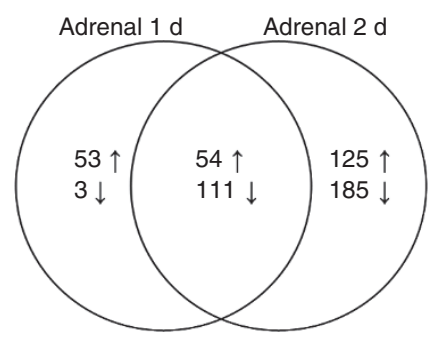

Figure 1. Summary of microarray gene expression profiles from the primary culture of human fetal adrenal cells. A primary culture of fetal adrenal cells was incubated under hypoxic conditions for $1 \mathrm{~d}$, followed by normoxic conditions for either 1 or $2 \mathrm{~d}$; control cells were maintained under hypoxic conditions throughout the experiment. (a) Gene expression levels were calculated as the signal levels under normoxic conditions divided by the signal levels under hypoxic conditions for control cells. (b) Venn diagram showing gene expression profiles in the primary culture of fetal adrenal cells incubated under the above conditions. Arrows pointing upward and downward represent increased and decreased numbers of expressed genes. and $\mathbf{S 2}$ online). Of these transcripts, 54 were increased and 111 were decreased on both days (Figure 1).

While this experiment showed that the hypoxic-normoxic transition can change the abundance of many adrenal mRNAs, changes were not seen in the transcripts for any gene encoding a steroidogenic enzyme or its electron-transfer cofactor. To examine mRNAs encoding steroidogenic factors more closely, we obtained additional adrenals, incubated primary adrenal cell cultures under hypoxic and normoxic conditions, and measured the relative abundances of selected mRNAs under each condition for each adrenal by reverse transcription followed by quantitative real-time PCR. Consistent with prior observations (21), preliminary experiments showed that the relative abundances of mRNAs for P450scc and P450c17 decreased after $4 \mathrm{~d}$ due to the overgrowth of fibroblasts and apoptosis of fetal adrenal cells (data not shown). Thus, we used $2 \mathrm{~d}$ of culture for more detailed studies with adrenals from five fetuses (three male and two female; 17-23 wk gestation). We noted no changes in the morphology of the adrenal cells after transition from hypoxia to normoxia for 1-2 d. Under normoxic conditions, the abundance of the mRNAs for P450c17, steroidogenic acute regulatory protein (StAR), and 3ßHSD2 increased after $2 \mathrm{~d}$ (Figure 2). Consistent with the data from other cell types (22), glyceraldehyde-3-phosphate dehydrogenase gene expression decreased in normoxia compared with hypoxia, but the expression of mRNAs for 3 $\beta \mathrm{HSD} 2$, StAR, and P $450 \mathrm{c} 17$ increased 2.6-, 2.0-, and 1.6-fold under normoxic conditions, while expression of P450scc barely changed. However, there was a substantial variation with the fetal adrenal cells from different fetuses, so that the statistical analyses were of marginal significance.

\section{Human Adrenal NCl-H295A Cells}

To avoid differences between individual fetal adrenals, we sought to use the immortalized human adrenal NCI-H295A cell line, in which the patterns of steroidogenesis closely

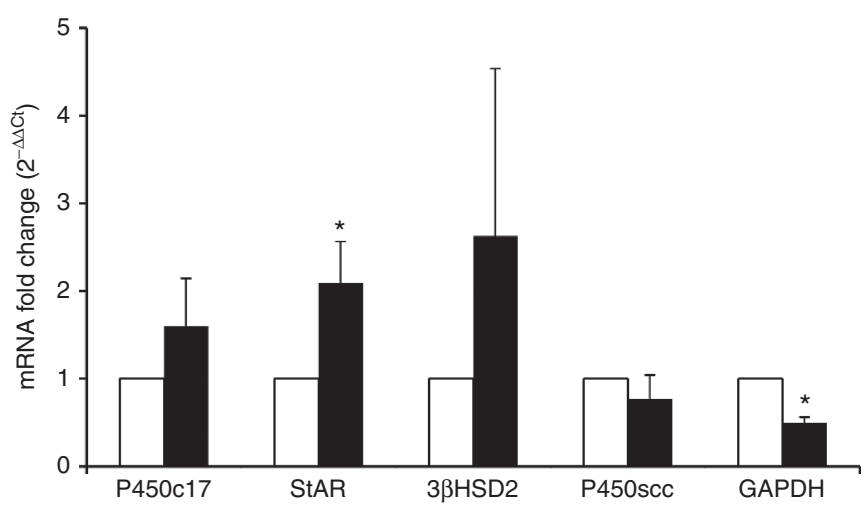

Figure 2. Expression of mRNAs in human fetal adrenal cells. Duplicate cultures of five fetal adrenals were grown in conditions of hypoxia (open bars) and normoxia (closed bars), and the mRNAs for P450c17, StAR, $3 \beta H S D 2, P 450 s c c$, and GAPDH were quantitated by qPCR. The mean levels in hypoxia are set at $100 \%$ for each RNA; data are mean \pm SEM; ${ }^{*} P<0.05$. $3 \beta \mathrm{HSD} 2$, 33-hydroxysteroid dehydrogenase, type 2; GAPDH, glyceraldehyde-3-phosphate dehydrogenase; P450c17, 17 $\alpha$-hydroxylase/17,20 lyase; qPCR, quantitative PCR; StAR, steroidogenic acute regulatory protein. 


\section{Articles | Agrawalet al.}

resemble those of the fetal adrenal (23). Because these cells are normally cultured in normoxic conditions, we first acclimated them to the fetal environment by culturing them in hypoxic conditions for $15 \mathrm{~d}$ before "delivering" them to extrauterine normoxic conditions for either 1 or $2 \mathrm{~d}$; control cells were maintained in hypoxic conditions throughout the experiment. We noted no changes in cellular morphology when the NCIH295A cells were transitioned from $15 \mathrm{~d}$ of hypoxia to normoxia. The resulting mRNAs were analyzed by hybridization to Illumina BeadChip microarrays, thus permitting analysis of the entire transcriptome. In NCI-H295A cells, only 4 mRNAs were increased and 56 were decreased when the cells were shifted from fetal hypoxic conditions to extrauterine normoxic conditions for $1 \mathrm{~d}$, and none of the altered mRNAs appeared to participate in steroidogenesis (Table 1 and Supplementary Table S3 online). By contrast, after the NCI-H295A cells had been returned to normoxia for $2 \mathrm{~d}, 62$ mRNAs were increased and 105 mRNAs were decreased (Table 2 and Supplementary Table S3 online). Among the mRNAs that increased, three encode proteins that participate in steroidogenesis: $\mathrm{P} 450 \mathrm{c} 17$ (CYP17A1), increased 1.65-fold; 3ßHSD2 (HSD3B2), increased 1.89-fold; and StAR (STAR), increased 1.78-fold over controls. In addition, sterol isomerase $(E B P)$, which participates in cholesterol biosynthesis, increased 1.57-fold. The degree of overlap in these gene populations is shown in Figure 3. These gene expression profiles showed that $46 \mathrm{mRNAs}$ were regulated in the same fashion after both 1 and 2 days of normoxia ( 1 increased and 45 decreased). In addition, the mRNAs for 3 other genes were increased and 11 were decreased after $1 \mathrm{~d}$ of normoxia and $61 \mathrm{mRNAs}$ were increased and 60 reduced after $2 \mathrm{~d}$ of normoxia.

Among the genes whose mRNAs increased or decreased under normoxic conditions (Tables 1 and 2), ALDOA, ALDOC, BNIP3, BNIP3L, CA9, ENO1, GADPH, HK2, IGFBP2, JMJD1A, LDHA, NDRG1, PKM2, SLC2A1, SLC2A3, and TPI1 are known to be transcriptionally regulated by hypoxia (24). Only four genes, BNIP3, NDRG1, SERPINA3, and SLC2A1 were regulated in common in both NCI-H295A cells and in the primary culture of fetal adrenal cells. The complete expression profile data for all genes in NCI-H295A and in the primary cultures of fetal adrenal cells are shown in Supplementary Tables S1-S4 online.

Gene ontology analyses using Ingenuity Pathway Analysis (https://analysis.ingenuity.com) showed that many of the repressed genes in NCI-H295A incubated for 1 or $2 \mathrm{~d}$ in normoxic conditions participate in common pathways such as glycolysis, sucrose degradation, vitamin $\mathrm{C}$ transport, thyroid hormone receptor/retinoid $\mathrm{X}$ receptor activation, and HIF1 $\alpha$ signaling (Tables 3-5). In contrast, the activated genes in NCI$\mathrm{H} 295 \mathrm{~A}$ are involved in glutathione-mediated detoxification, dendritic-natural killer cells crosstalk, p53 signaling, and, of course, steroidogenesis.

\section{DISCUSSION}

Little information is available concerning the potential effects of environmental oxygenation on fetal adrenal function, and most such reports have investigated animal models of highaltitude stress. Thus, when pregnant rats were transitioned to reduced air pressure of $\sim 380$ Torr $\left(\sim 50 \mathrm{kPa} ; \mathrm{Po}_{2} \sim 10 \mathrm{kPa}\right.$; designed to correspond to 18,000 feet above sea level), the adrenals of fetuses were larger, possibly due to increased adrenocorticotropic hormone secretion (25). Long-term maintenance of pregnant sheep at 3,820 m above sea level $\left(\mathrm{Po}_{2} \sim 102\right.$ Torr; $13.6 \mathrm{kPa}$ ) reduced expression of mRNAs and proteins for P450scc, P450c17, and MC2R (adrenocorticotropic hormone receptor) but did not alter P450c21 (21-hydroxylase, encoded by CYP21A2), StAR (encoded by STAR), 3ßHSD2, or DAX-1 (26). At birth, the fetal zone of the human adrenal cortex involutes rapidly, as evidenced by rapidly declining serum concentrations of DHEA and DHEAS. Furthermore, this rapid decline in DHEA/S is seen in both premature and term infants (27). Therefore, we and others have hypothesized that the involution of the fetal adrenal is not "programmed" but "triggered." A current view is that the trigger is the loss of placental hormones and growth factors (20). Such a trigger could also be secondary to the profound environmental change that accompanies birth. Such changes initiate the transition from fetal to postnatal circulatory patterns, including closure of the foramen ovale and the ductus arteriosus. Closure of the ductus is directly triggered by increased oxygen tension (via prostaglandins), and many other events in the newborn are triggered by the transition to normoxia (28). Thus, we hypothesized that the transition from the intrauterine hypoxic environment to the extrauterine normoxic environment might participate in initiating the rapid changes in adrenal steroidogenesis that follow birth. The fetal adrenal and other organs served by the fetal abdominal aorta are bathed in oxygen-poor blood having a partial pressure of oxygen of about $20-22$ Torr $(2.6-2.9 \mathrm{kPa})$ (29). Therefore, to model the changes in the adrenal environment that accompany birth, we incubated human fetal adrenal cells and human adrenal NCI-H295A cells in $2 \%$ oxygen (hypoxia, $\mathrm{Po}_{2} \sim 2.0 \mathrm{kPa}$ ) followed by incubation in atmospheric oxygen (normoxia, $\sim 20 \mathrm{kPa}$ ) for 1 and $2 \mathrm{~d}$.

Results with human fetal adrenals suggested that the hypoxic-normoxic transition increased the mRNAs for StAR, 33HSD2, and P450c17 and decreased the mRNA for P450scc, but only the data with StAR reached nominal significance of $P$ $<0.05$. There was substantial variation among adrenals from different donors, with no pattern attributable to donor sex or gestational age in the 17-23-wk period used. Therefore, we turned to human adrenocortical carcinoma NCI-H295A cells, which possess features typical of fetal, rather than adult, adrenal cells (e.g., expression of IGF-2 and P450aro) (23). The cells were propagated in hypoxic conditions for $15 \mathrm{~d}$ to acclimate them to this model intrauterine environment before "delivering" them to normoxia. This transition induced changes in the abundance of many mRNAs, with many more changes after 2 $\mathrm{d}$ than after $1 \mathrm{~d}$. Not surprisingly, one of the induced genes was HIF1A, which encodes a hypoxia-induced transcription factor (30). Most notably, after $2 \mathrm{~d}$ of normoxia, the abundances of the mRNAs for the steroidogenic factors $3 \beta \mathrm{HSD} 2$, StAR, and P450c17 increased $>1.6$-fold. This will change the pattern of 
Table 1. Expression of 4 genes activated and 56 genes inhibited in $\mathrm{NCl}-\mathrm{H} 295 \mathrm{~A}$ cells incubated under hypoxic conditions for $15 \mathrm{~d}$, followed by normoxic conditions for $1 \mathrm{~d}$

\begin{tabular}{|c|c|c|c|c|}
\hline Symbol & Gene & Mean $\pm S D^{a}$ & Chromosome & Function \\
\hline MIR1974 & MicroRNA 1974 & $1.68 \pm 1.26$ & & MicroRNA \\
\hline UCK2 & Uridine-cytidine kinase 2 & $1.51 \pm 0.16$ & 1 & Pyrimidine metabolism \\
\hline GINS4 & GINS complex subunit 4 (SId5 homolog) & $1.50 \pm 0.67$ & 8 & $\begin{array}{l}\text { Initiation of DNA replication and } \\
\text { progression of DNA replication forks }\end{array}$ \\
\hline LOC100132564 & Hypothetical protein LOC100132564 & $0.66 \pm 0.27$ & 12 & Unknown \\
\hline RNU1-3 & U1 small nuclear 3 & $0.66 \pm 0.22$ & 1 & Component of the spliceosome \\
\hline SNORA28 & Small nucleolar RNA, H/ACA box 28 & $0.66 \pm 0.07$ & 14 & Unknown \\
\hline NARF & Nuclear prelamin A recognition factor & $0.66 \pm 0.03$ & 17 & $\begin{array}{l}\text { Binds to the prenylated prelamin A } \\
\text { carboxyl-terminal tail domain }\end{array}$ \\
\hline MT1H & Metallothionein $1 \mathrm{H}$ & $0.65 \pm 0.18$ & 16 & Protein binding and zinc ion binding \\
\hline LOC728188 & Similar to phosphoglycerate mutase processed protein & $0.65 \pm 0.11$ & $x$ & Unknown \\
\hline WDR54 & WD repeat domain 54 & $0.65 \pm 0.07$ & 2 & Unknown \\
\hline PGK1 & Phosphoglycerate kinase 1 & $0.64 \pm 0.06$ & $x$ & Glycolysis/gluconeogenesis \\
\hline MTP18 & Mitochondrial protein $18 \mathrm{kDa}$ & $0.64 \pm 0.04$ & 22 & Mitochondrial division \\
\hline HIG-2 & Hypoxia-inducible lipid droplet-associated & $0.64 \pm 0.02$ & 7 & Intracellular lipid accumulation \\
\hline SNX26 & Sorting nexin 26 & $0.63 \pm 0.03$ & 19 & Intracellular trafficking \\
\hline RNU1A3 & RNA, U1A3 small nuclear & $0.63 \pm 0.20$ & 1 & Component of the spliceosome \\
\hline SLC6A8 & $\begin{array}{l}\text { Solute carrier family } 6 \text { (neurotransmitter transporter, } \\
\text { creatine), member } 8\end{array}$ & $0.63 \pm 0.10$ & $x$ & Creatine uptake in muscles and brain \\
\hline$S L C 2 A 3^{b}$ & $\begin{array}{l}\text { Solute carrier family } 2 \text { (facilitated glucose transporter), } \\
\text { member } 3\end{array}$ & $0.62 \pm 0.03$ & 12 & Glucose transporter \\
\hline ORM1 & Orosomucoid 1 & $0.62 \pm 0.03$ & 9 & Transport protein in the blood stream \\
\hline GPI & Glucose phosphate isomerase & $0.61 \pm 0.06$ & 19 & Glycolysis/gluconeogenesis \\
\hline LOC732165 & $\begin{array}{l}\text { Similar to triosephosphate isomerase (TIM) (triose- } \\
\text { phosphate isomerase) }\end{array}$ & $0.61 \pm 0.07$ & 1 & Unknown \\
\hline ADSSL1 & Adenylosuccinate synthase like 1 & $0.60 \pm 0.07$ & 14 & Component of the purine nucleotide cycle \\
\hline MGC16121 & Hypothetical protein MGC16121 & $0.60 \pm 0.07$ & $x$ & Unknown \\
\hline $\mathrm{GAPDH}^{\mathrm{b}}$ & Glyceraldehyde-3-phosphate dehydrogenase & $0.60 \pm 0.06$ & 12 & Glycolysis/gluconeogenesis \\
\hline EFHD2 & EF-hand domain family, member D2 & $0.59 \pm 0.04$ & 1 & Calcium ion binding, protein binding \\
\hline $\mathrm{TPI} 1^{\mathrm{b}}$ & Triosephosphate isomerase 1 & $0.59 \pm 0.09$ & 12 & Glycolysis/gluconeogenesis \\
\hline PNCK & $\begin{array}{l}\text { Pregnancy upregulated nonubiquitously expressed CaM } \\
\text { kinase }\end{array}$ & $0.59 \pm 0.12$ & $\mathrm{x}$ & Calcium signaling \\
\hline TMEM45A & Transmembrane protein $45 \mathrm{~A}$ & $0.58 \pm 0.07$ & 3 & Unknown \\
\hline RN7SK & RNA, 7SK small nuclear & $0.57 \pm 0.19$ & 6 & Unknown \\
\hline LOC732007 & $\begin{array}{l}\text { Similar to phosphoglycerate mutase } 1 \text { (phosphoglycerate } \\
\text { mutase isozyme B) (PGAM-B) (BPG-dependent PGAM 1) }\end{array}$ & $0.57 \pm 0.08$ & 12 & Unknown \\
\hline
\end{tabular}

Table 1. Continued on next page 


\section{Articles | Agrawalet al.}

Table 1. Continued

\begin{tabular}{|c|c|c|c|c|}
\hline Symbol & Gene & Mean $\pm S D^{a}$ & Chromosome & Function \\
\hline PLOD1 & Procollagen-lysine 1, 2-oxoglutarate 5-dioxygenase 1 & $0.56 \pm 0.09$ & 1 & Lysine degradation \\
\hline JMJD1 $A^{b}$ & Jumonji domain containing $1 \mathrm{~A}$ & $0.55 \pm 0.06$ & 2 & Histone demethylation \\
\hline TPI1P2 & Triosephosphate isomerase 1 pseudogene 2 & $0.54 \pm 0.01$ & 7 & Unknown \\
\hline PFKP & Phosphofructokinase, platelet & $0.53 \pm 0.08$ & 10 & $\begin{array}{l}\text { Fructose and mannose metabolism; } \\
\text { galactose metabolism; glycolysis/ } \\
\text { gluconeogenesis }\end{array}$ \\
\hline SLC6A10P & $\begin{array}{l}\text { Solute carrier family } 6 \text { (neurotransmitter transporter, } \\
\text { creatine), member } 10\end{array}$ & $0.52 \pm 0.10$ & 16 & Unknown \\
\hline $\mathrm{ENO}^{\mathrm{b}}$ & Enolase 1, (alpha) & $0.51 \pm 0.04$ & 1 & Glycolysis/gluconeogenesis \\
\hline TPI1P1 & Triosephosphate isomerase 1 pseudogene 1 & $0.50 \pm 0.06$ & 1 & Unknown \\
\hline $\mathrm{PKM}^{\mathrm{b}}$ & Pyruvate kinase, muscle & $0.49 \pm 0.08$ & 15 & Glycolysis/gluconeogenesis \\
\hline BNIP3L ${ }^{b}$ & $\mathrm{BCL} 2 /$ adenovirus E1B $19 \mathrm{kDa}$ interacting protein 3-like & $0.47 \pm 0.01$ & 8 & Apoptosis \\
\hline LOC644774 & Similar to phosphoglycerate kinase 1 & $0.45 \pm 0.02$ & $\mathrm{x}$ & Unknown \\
\hline SPRR2F & Small proline-rich protein $2 \mathrm{~F}$ & $0.45 \pm 0.11$ & 1 & Structural constituent of cytoskeleton \\
\hline DDIT4 & DNA-damage-inducible transcript 4 & $0.45 \pm 0.09$ & 10 & $\begin{array}{l}\text { Inhibits cell growth by regulating the } \\
\text { mTOR signaling pathway }\end{array}$ \\
\hline $\mathrm{SLC} 2 \mathrm{~A} 1^{\mathrm{b}}$ & $\begin{array}{l}\text { Solute carrier family } 2 \text { (facilitated glucose transporter), } \\
\text { member } 1\end{array}$ & $0.44 \pm 0.03$ & 1 & Glucose transporter \\
\hline $\mathrm{ALDOC}^{\mathrm{b}}$ & Aldolase C, fructose-bisphosphate & $0.41 \pm 0.07$ & 17 & Glycolysis and gluconeogenesis \\
\hline PFKFB4 & 6-phosphofructo-2-kinase/fructose-2,6-biphosphatase 4 & $0.18 \pm 0.05$ & 3 & Fructose and mannose metabolism \\
\hline
\end{tabular}

CAMP, cyclic adenosine monophosphate; mTOR, mammalian target of rapamycin.

aThe data are expressed as mean fold change in normoxic conditions over control in hypoxic conditions \pm SD. ${ }^{b}$ Positive control genes known to be transcriptionally regulated by hypoxia.

steroidogenesis from $\Delta 5$ to $\Delta 4$ steroids, as is seen following birth.

Our study emphasizes analysis of mRNAs and did not measure the abundances of steroidogenic enzyme proteins or the steroid products of our adrenal cell systems; such measurements will be of interest in future studies. In addition, our experimental design only examined events in the first $2 \mathrm{~d}$ following the transition to normoxia, yet the involution of the fetal adrenal and the transition from fetal to newborn pattern of steroidogenesis takes several weeks, so that future studies may also examine a broader time frame. However, it seems likely that the rapid changes in oxygenation at delivery would constitute an acute trigger to change the adrenal's transcriptional programming and that such acute changes would subsequently affect adrenal morphology and steroid secretory patterns over the first weeks of life, so we would expect that the changes in mRNA abundances that we have measured would precede changes in adrenal morphology and steroid secretion. In this context, it may be important to add tropic activators of the protein kinase A pathway (adrenocorticotropic hormone to adrenal cells and 8-Br-cAMP to NCI-H295A cells), to mimic conditions in vivo.

Our data are consistent with our hypothesis that the change in oxygenation that follows birth is a key factor in determining the change in the patterns of adrenal steroidogenesis that follow birth. However, no aspect of our data is inconsistent with the hypothesis that withdrawal of placental factors also plays a role, especially in the rapid involution of adrenal size, as known adrenal growth factors (IGF-2, EGF, FGF) (31) were not among the factors dramatically changed by the hypoxicnormoxic transition in our studies. Thus, we propose that both the hypoxic-normoxic transition and the potential withdrawal of placental factors are required to initiate the anatomic 
Table 2. Expression of 62 genes activated and 105 genes inhibited in $\mathrm{NCl}-\mathrm{H} 295 \mathrm{~A}$ cells incubated under hypoxic conditions for $15 \mathrm{~d}$, followed by normoxic conditions for $2 \mathrm{~d}$

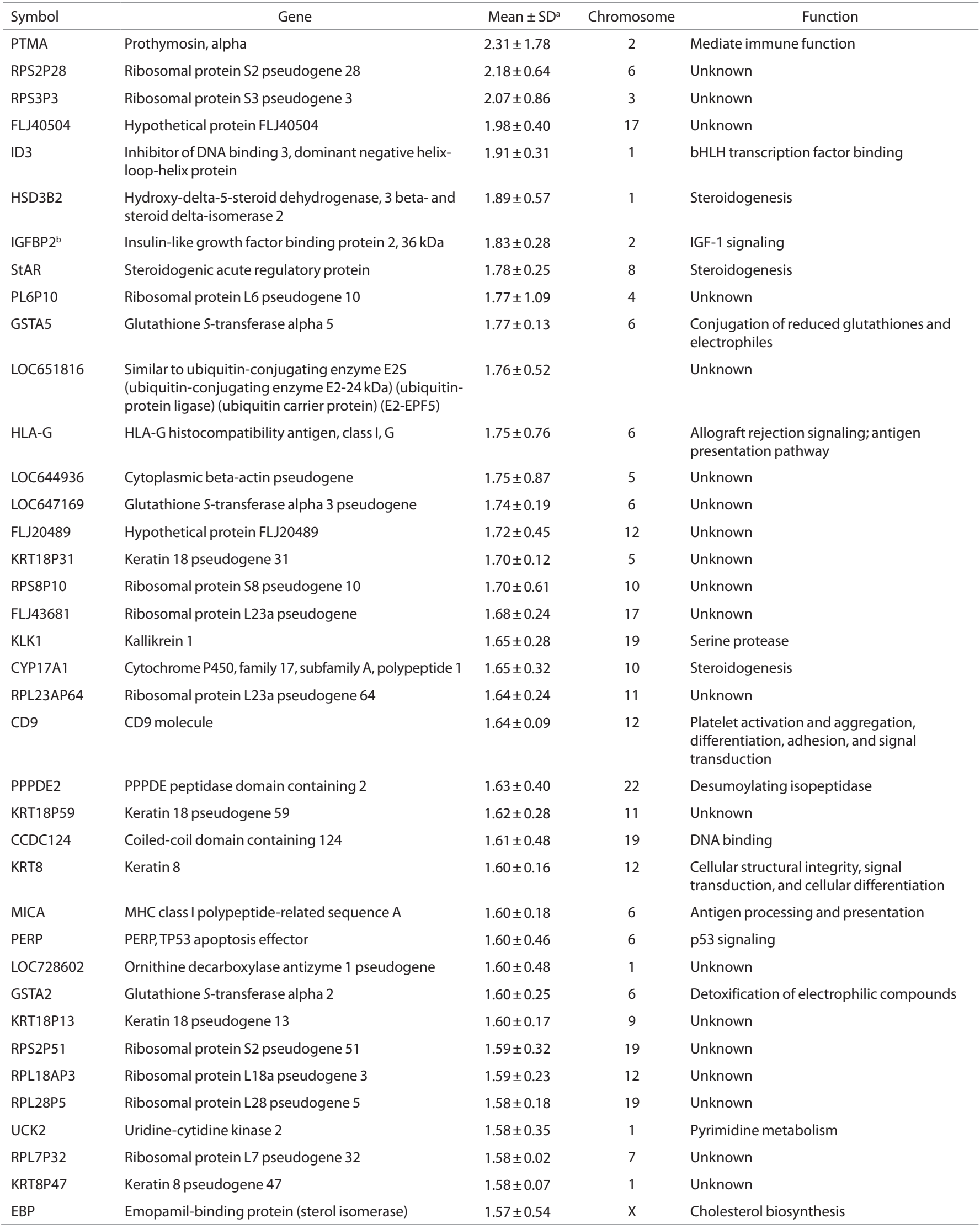

Table 2. Continued on next page 


\section{Articles | Agrawal et al.}

Table 2. Continued

\begin{tabular}{|c|c|c|c|c|}
\hline Symbol & Gene & Mean $\pm S D^{a}$ & Chromosome & Function \\
\hline CKB & Creatine kinase, brain & $1.57 \pm 0.29$ & 14 & $\begin{array}{l}\text { Transfer of phosphate between ATP and } \\
\text { phosphogens }\end{array}$ \\
\hline LOC389672 & $\begin{array}{l}\text { Similar to } 40 \text { S ribosomal protein SA (p40) }(34 / 67 \mathrm{kDa} \\
\text { laminin receptor) (colon carcinoma laminin-binding } \\
\text { protein) (NEM/1CHD4) (multidrug resistance- } \\
\text { associated protein MGr1-Ag) }\end{array}$ & $1.56 \pm 0.47$ & 8 & Unknown \\
\hline CATSPER2 & Cation channel, sperm associated 2 & $1.56 \pm 0.77$ & 15 & Voltage-gated calcium channel \\
\hline NOP16 & NOP16 nucleolar protein homolog (yeast) & $1.55 \pm 0.16$ & 5 & Unknown \\
\hline LOC100134053 & Similar to POLR2J4 protein & $1.55 \pm 0.24$ & 7 & Unknown \\
\hline XBP1 & X-box binding protein 1 & $1.55 \pm 0.18$ & 22 & Endoplasmic reticulum stress pathway \\
\hline HMGN2P25 & $\begin{array}{l}\text { High mobility group nucleosomal binding domain } 2 \\
\text { pseudogene } 25\end{array}$ & $1.53 \pm 0.25$ & 3 & Unknown \\
\hline PPIB & Peptidylprolyl isomerase B (cyclophilin B) & $1.53 \pm 0.20$ & 15 & Folding of proteins \\
\hline LOC100129502 & Hypothetical protein LOC100129502 & $1.53 \pm 0.42$ & 15 & Unknown \\
\hline SDF2L1 & Stromal cell-derived factor 2-like 1 & $1.53 \pm 0.21$ & 22 & Unknown \\
\hline DCXR & Dicarbonyl/L-xylulose reductase & $1.52 \pm 0.15$ & 17 & $\begin{array}{l}\text { Uronate cycle of glucose metabolism; } \\
\text { osmoregulation in renal tubules }\end{array}$ \\
\hline RPS26P35 & Ribosomal protein S26 pseudogene 35 & $1.52 \pm 0.24$ & 8 & Unknown \\
\hline LOC651149 & Similar to 60 S ribosomal protein $L 3(\mathrm{~L} 4)$ & $1.52 \pm 0.09$ & 10 & Unknown \\
\hline ADI1 & Acireductone dioxygenase 1 & $1.52 \pm 0.46$ & 2 & $\begin{array}{l}\text { Catalyzes the formation of formate } \\
\text { and 2-keto-4-methylthiobutyrate from } \\
\text { 1,2-dihydroxy-3-keto-5-methylthiopentene }\end{array}$ \\
\hline RPL29P15 & Ribosomal protein L29 pseudogene 15 & $1.50 \pm 0.32$ & 5 & Unknown \\
\hline HIF1A & Hypoxia-inducible factor 1 , alpha subunit & $1.50 \pm 0.45$ & 14 & $\begin{array}{l}\text { Basic helix-loop-helix transcription factor } \\
\text { activated in response to reduced oxygen } \\
\text { availability in the cellular environment }\end{array}$ \\
\hline SNORD13 & Small nucleolar RNA, C/D box 13 & $0.66 \pm 0.11$ & 8 & Unknown \\
\hline MTMR11 & Myotubularin-related protein 11 & $0.66 \pm 0.06$ & 1 & Probable pseudophosphatase \\
\hline MXD4 & MAX dimerization protein 4 & $0.66 \pm 0.04$ & 4 & Transcriptional repressor \\
\hline KANK4 & KN motif and ankyrin repeat domains 4 & $0.66 \pm 0.14$ & 1 & $\begin{array}{l}\text { Control of cytoskeleton formation by } \\
\text { regulating actin polymerization }\end{array}$ \\
\hline WDR54 & WD repeat domain 54 & $0.66 \pm 0.19$ & 2 & Unknown \\
\hline RNU1G2 & RNA, U1G2 small nuclear & $0.65 \pm 0.22$ & 1 & Unknown \\
\hline MYLK4 & Myosin light chain kinase family, member 4 & $0.65 \pm 0.07$ & 6 & $\begin{array}{l}\text { Protein serine/threonine kinase activity and } \\
\text { ATP binding }\end{array}$ \\
\hline HOXA5 & Homeobox A5 & $0.65 \pm 0.15$ & 7 & Transcription factor \\
\hline MT1H & Metallothionein $1 \mathrm{H}$ & $0.65 \pm 0.06$ & 16 & Protein binding and zinc ion binding \\
\hline RHBDL3 & Rhomboid, veinlet-like 3 (Drosophila) & $0.65 \pm 0.05$ & 17 & Intramembrane proteolysis \\
\hline GOLGA8B & Golgin A8 family, member B & $0.64 \pm 0.11$ & 15 & Maintaining Golgi structure \\
\hline UBA7 & Ubiquitin-like modifier activating enzyme 7 & $0.64 \pm 0.04$ & 3 & Activates ubiquitin \\
\hline
\end{tabular}

Table 2. Continued on next page 
Table 2. Continued

\begin{tabular}{|c|c|c|c|c|}
\hline Symbol & Gene & Mean $\pm S D^{a}$ & Chromosome & Function \\
\hline C15orf52 & Chromosome 15 open reading frame 52 & $0.64 \pm 0.05$ & 15 & Unknown \\
\hline PLOD2 & Procollagen-lysine, 2-oxoglutarate 5-dioxygenase 2 & $0.64 \pm 0.02$ & 3 & Lysine degradation \\
\hline TAF1C & $\begin{array}{l}\text { TATA box binding protein (TBP)-associated factor, RNA } \\
\text { polymerase I, C, } 110 \mathrm{kDa}\end{array}$ & $0.64 \pm 0.02$ & 16 & $\begin{array}{l}\text { Component of the transcription factor SL1/ } \\
\text { TIF-IB complex }\end{array}$ \\
\hline SLC6A8 & $\begin{array}{l}\text { Solute carrier family } 6 \text { (neurotransmitter transporter, } \\
\text { creatine), member } 8\end{array}$ & $0.64 \pm 0.10$ & $\mathrm{x}$ & Creatine uptake in muscles and brain \\
\hline TPI1P1 & Triosephosphate isomerase 1 pseudogene 1 & $0.64 \pm 0.10$ & 1 & Unknown \\
\hline $\mathrm{ALDOA}^{\mathrm{b}}$ & Aldolase A, fructose-bisphosphate & $0.64 \pm 0.07$ & 16 & Glycolysis and gluconeogenesis \\
\hline KLHL3 & Kelch-like 3 (Drosophila) & $0.63 \pm 0.02$ & 5 & $\begin{array}{l}\text { Substrate-specific adapter of a BTB-CUL3- } \\
\text { RBX1 E3 ubiquitin ligase complex }\end{array}$ \\
\hline DDIT4L & DNA-damage-inducible transcript 4-like & $0.63 \pm 0.07$ & 4 & $\begin{array}{l}\text { Inhibits cell growth by regulating the mTOR } \\
\text { signaling pathway }\end{array}$ \\
\hline DPYSL4 & Dihydropyrimidinase-like 4 & $0.63 \pm 0.03$ & 10 & $\begin{array}{l}\text { Signaling by class } 3 \text { semaphorins and } \\
\text { subsequent remodeling of the cytoskeleton }\end{array}$ \\
\hline KLF2 & Kruppel-like factor 2 (lung) & $0.63 \pm 0.04$ & 19 & $\begin{array}{l}\text { Binds CACCC box in the beta-globin gene } \\
\text { promoter and activates transcription }\end{array}$ \\
\hline RNU6-1 & RNA, U6 small nuclear 1 & $0.63 \pm 0.17$ & 15 & Unknown \\
\hline COL11A1 & Collagen, type XI, alpha 1 & $0.63 \pm 0.08$ & 1 & Fibrillogenesis \\
\hline ANKRD37 & Ankyrin repeat domain 37 & $0.62 \pm 0.05$ & 4 & Unknown \\
\hline ZNF395 & Zinc finger protein 395 & $0.62 \pm 0.04$ & 8 & Unknown \\
\hline SNORD113-5 & Small nucleolar RNA, C/D box $113-5$ & $0.62 \pm 0.05$ & 14 & Unknown \\
\hline ABP1 & $\begin{array}{l}\text { Amiloride binding protein } 1 \text { (amine oxidase (copper- } \\
\text { containing) }\end{array}$ & $0.62 \pm 0.14$ & 7 & $\begin{array}{l}\text { Degradation of putrescine, histamine, } \\
\text { spermine, and spermidine }\end{array}$ \\
\hline ZBTB40 & Zinc finger and BTB domain containing 40 & $0.62 \pm 0.07$ & 1 & Unknown \\
\hline TMEM123 & Transmembrane protein 123 & $0.61 \pm 0.17$ & 11 & Oncotic cell death \\
\hline RN5S9 & RNA, 5 S ribosomal 9 & $0.61 \pm 0.27$ & 1 & Unknown \\
\hline RNU1F1 & RNA, U1F1 small nuclear & $0.61 \pm 0.22$ & 14 & Component of the spliceosome \\
\hline WDR90 & WD repeat domain 90 & $0.61 \pm 0.07$ & 16 & Unknown \\
\hline RNU6-15 & RNA, U6 small nuclear 15 & $0.61 \pm 0.15$ & - & Unknown \\
\hline CLCNKA & Chloride channel Ka & $0.60 \pm 0.01$ & 1 & Voltage-gated chloride channel \\
\hline SNORD3C & Small nucleolar RNA, C/D box $3 C$ & $0.60 \pm 0.12$ & 17 & Unknown \\
\hline SIRPA & Signal-regulatory protein alpha & $0.60 \pm 0.07$ & 20 & $\begin{array}{l}\text { Immunoglobulin-like cell surface receptor } \\
\text { for CD47 }\end{array}$ \\
\hline TPI1 ${ }^{\mathrm{b}}$ & Triosephosphate isomerase 1 & $0.60 \pm 0.04$ & 12 & Unknown \\
\hline SLC27A3 & $\begin{array}{l}\text { Solute carrier family } 27 \text { (fatty acid transporter), } \\
\text { member } 3\end{array}$ & $0.60 \pm 0.09$ & 1 & Acyl-CoA ligase activity \\
\hline
\end{tabular}

Table 2. Continued on next page 


\section{Articles | Agrawal et al.}

Table 2. Continued

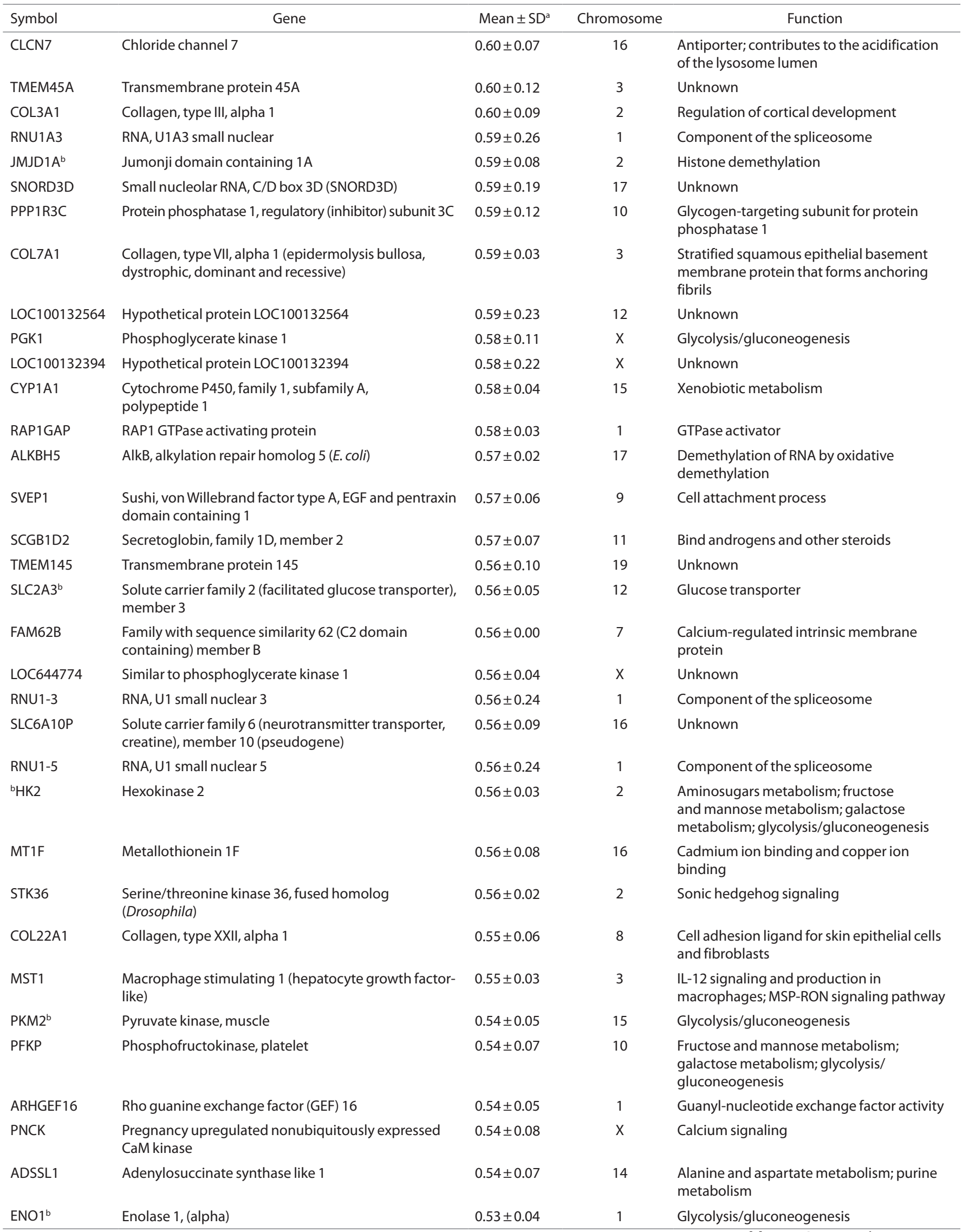

Table 2. Continued on next page 
Table 2. Continued

\begin{tabular}{|c|c|c|c|c|}
\hline Symbol & Gene & Mean $\pm S D^{a}$ & Chromosome & Function \\
\hline SSPO & SCO-spondin homolog (Bos taurus) & $0.53 \pm 0.05$ & 7 & Modulation of neuronal aggregation \\
\hline PGM1 & Phosphoglucomutase 1 & $0.51 \pm 0.05$ & 1 & Glycolysis/gluconeogenesis \\
\hline MGC16121 & Hypothetical protein MGC16121 & $0.51 \pm 0.08$ & $x$ & Unknown \\
\hline VIL2 & Villin 2 (ezrin) & $0.51 \pm 0.07$ & 6 & Actin cytoskeleton signaling \\
\hline RFTN1 & Raftlin, lipid raft linker 1 & $0.51 \pm 0.02$ & 3 & Formation and/or maintenance of lipid rafts \\
\hline EZR & Ezrin & $0.50 \pm 0.11$ & 6 & Actin cytoskeleton signaling \\
\hline DDIT4 & DNA-damage-inducible transcript 4 & $0.49 \pm 0.09$ & 10 & $\begin{array}{l}\text { Inhibits cell growth by regulating the mTOR } \\
\text { signaling pathway }\end{array}$ \\
\hline $\operatorname{SLC} 2 A 1^{b}$ & $\begin{array}{l}\text { Solute carrier family } 2 \text { (facilitated glucose transporter), } \\
\text { member } 1\end{array}$ & $0.47 \pm 0.03$ & 1 & Glucose transporter \\
\hline RN7SK & RNA, 7SK small nuclear & $0.43 \pm 0.18$ & 6 & Pre-mRNA splicing and processing \\
\hline $\mathrm{LDHA}^{\mathrm{b}}$ & Lactate dehydrogenase $\mathrm{A}$ & $0.43 \pm 0.02$ & 11 & Glycolysis/gluconeogenesis \\
\hline$B N I P 3 L^{b}$ & BCL2/adenovirus E1B $19 \mathrm{kDa}$ interacting protein 3-like & $0.41 \pm 0.02$ & 8 & Apoptosis \\
\hline RNU4-2 & RNA, U4 small nuclear 2 & $0.41 \pm 0.19$ & & Pre-mRNA splicing and processing \\
\hline ALDOC $^{b}$ & Aldolase C, fructose-bisphosphate & $0.41 \pm 0.12$ & 17 & Glycolysis and gluconeogenesis \\
\hline ORM1 & Orosomucoid 1 & $0.39 \pm 0.09$ & 9 & Transport protein in the blood stream \\
\hline SERPINA3 & $\begin{array}{l}\text { Serpin peptidase inhibitor, clade A (alpha-1 } \\
\text { antiproteinase, antitrypsin), member } 3\end{array}$ & $0.33 \pm 0.08$ & 14 & Plasma protease inhibitor \\
\hline BHLHB2 & Basic helix-loop-helix domain containing, class B, 2 & $0.32 \pm 0.09$ & 3 & $\begin{array}{l}\text { Transcriptional factor modulating } \\
\text { chondrogenesis in response to the CAMP } \\
\text { pathway }\end{array}$ \\
\hline
\end{tabular}

CAMP, cyclic adenosine monophosphate; mTOR, mammalian target of rapamycin.

aThe data are expressed as mean fold change in normoxic conditions over control in hypoxic conditions \pm SD. bPositive control genes known to be transcriptionally regulated by hypoxia.

Table 3. Pathway analysis of genes downregulated in NCI-H295A cells incubated in hypoxic conditions for $15 \mathrm{~d}$, followed by normoxic conditions for $1 \mathrm{~d}$

\begin{tabular}{lcl}
\hline Canonical pathways & \multicolumn{1}{c}{$P$ value } & \multicolumn{1}{c}{ Molecules } \\
\hline Glycolysis & $2.51 \times 10^{-23}$ & PGK1, ENO1, GPI, TPI1, PGAM1, \\
& & PKM2, GAPDH, ALDOA, PFKP, ALDOC \\
Sucrose degradation & $3.55 \times 10^{-7}$ & TPI1, ALDOA, ALDOC \\
Vitamin C transport & $2.29 \times 10^{-3}$ & SLC2A1, SLC2A3 \\
TR/RXR activation & $3.80 \times 10^{-3}$ & ENO1, SLC2A1, PFKP \\
HIF1 $\alpha$ signaling & $5.50 \times 10^{-3}$ & SLC2A1, LDHA, SLC2A3 \\
\hline
\end{tabular}

TR/RXR, thyroid hormone receptor/retinoid $X$ receptor.

remodeling of the fetal adrenal and its change in steroidogenic patterns as the fetus transitions to extrauterine life. While there may be differences among expression levels of mRNAs, their encoded proteins, and downstream steroids, our preliminary data suggest that the hypoxic/normoxic transition at birth is likely to be an important component of the perinatal changes in adrenal architecture and steroidogenesis.

\section{METHODS \\ Cells}

We used two cell systems. First, we used primary cultures from human fetal adrenals obtained with written consent from women undergoing elective procedures at San Francisco General Hospital. This research was performed with Institutional Review Board approval from the University of California San Francisco's Committee on Human Research. All specimens were anonymous. The gestational age of the fetal specimens was estimated based on foot length. Second, we used the NCI-H295A human adrenocortical cell line (32) that expresses all adrenal steroidogenic enzymes (23) and has been selected to grow in monolayer (33). All cells were grown in Roswell Park Memorial Institute (RPMI) medium (UCSF cell culture facility) with $2 \%$ fetal bovine serum. All experiments were performed in triplicate. Hypoxic conditions consisted of an atmosphere of $2 \%$ oxygen, $93 \%$ nitrogen, and $5 \% \mathrm{CO}_{2}$ in the XVIVO hypoxia tissue culture hood from 
a Total number of genes activated or inhibited in NCl-H295A cells in normoxia over control in hypoxia:

$1 \mathrm{~d}$ normoxia, 60 genes $(4 \uparrow+56 \downarrow)$

$2 \mathrm{~d}$ normoxia, 167 genes $(62 \uparrow+105 \downarrow)$

b

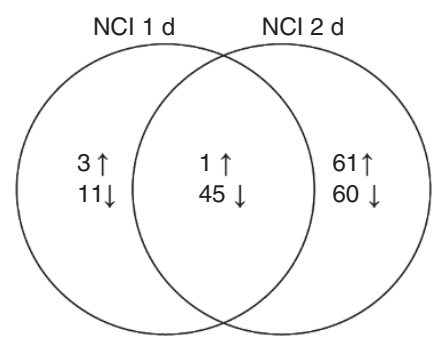

Figure 3. Summary of microarray gene expression profiles from $\mathrm{NCl}-\mathrm{H} 295 \mathrm{~A}$ cells. $\mathrm{NCl}-\mathrm{H} 295 \mathrm{~A}$ cells were incubated under hypoxic conditions for $15 \mathrm{~d}$, followed by normoxic conditions for either $1 \mathrm{~d}$ or $2 \mathrm{~d}$, while control cells were maintained under hypoxic conditions throughout the experiment. (a) Gene expression levels were calculated as the signal levels under normoxic conditions divided by the signal levels under hypoxic conditions for control cells. A fold change cutoff of $>1.5$-fold or $<0.67$-fold over control was chosen in our study. (b) Venn diagram showing gene expression profiles in $\mathrm{NCl}-\mathrm{H} 295 \mathrm{~A}$ cells incubated under the above conditions. Arrows pointing upward and downward represent increased and decreased gene expression.

Table 4. Pathway analysis of genes upregulated in $\mathrm{NCl}-\mathrm{H} 295 \mathrm{~A}$ cells incubated in hypoxic conditions for $15 \mathrm{~d}$, followed by normoxic conditions for $2 \mathrm{~d}$

\begin{tabular}{|c|c|c|}
\hline Canonical pathways & $P$ value & Molecules \\
\hline $\begin{array}{l}\text { Glutathione-mediated } \\
\text { detoxification }\end{array}$ & $2.04 \times 10^{-7}$ & GSTA2, GSTA5 \\
\hline Steroidogenesis & $8.51 \times 10^{-7}$ & $\begin{array}{l}\text { CYP17A1, EBP, } \\
\text { HSD3B2, StAR }\end{array}$ \\
\hline $\begin{array}{l}\text { Crosstalk between dendritic cells } \\
\text { and natural killer cells }\end{array}$ & $3.63 \times 10^{-3}$ & HLA-G, MICA \\
\hline p53 signaling & $4.37 \times 10^{-2}$ & PERP, HIF1A \\
\hline
\end{tabular}

Table 5. Pathway analysis of genes downregulated in $\mathrm{NCl}-\mathrm{H} 295 \mathrm{~A}$ cells incubated in hypoxic conditions for $15 \mathrm{~d}$, followed by normoxic conditions for $2 \mathrm{~d}$

\begin{tabular}{lcl}
\hline Canonical pathways & $P$ value & \multicolumn{1}{c}{ Molecules } \\
\hline Glycolysis & $3.16 \times 10^{-12}$ & $\begin{array}{l}\text { PGK1, ENO1, GPI, TPI1, } \\
\text { PKM2, ALDOA, PFKP, ALDOC }\end{array}$ \\
$\begin{array}{l}\text { Sucrose degradation } \\
\text { Systemic lupus }\end{array}$ & $4.47 \times 10^{-6}$ & TPI1, ALDOA, ALDOC \\
erythematosus signaling & $6.17 \times 10^{-4}$ & RNU1-3, RNU4-2, RNU6-1 \\
Estrogen biosynthesis & $3.31 \times 10^{-3}$ & CYP1A1, CYP2J2 \\
Vitamin C transport & $7.76 \times 10^{-3}$ & SLC2A1, SLC2A3 \\
TR/RXR activation & $2.09 \times 10^{-2}$ & ENO1, SLC2A1, PFKP \\
HIF1 $\alpha$ signaling & $2.95 \times 10^{-2}$ & SLC2A1, LDHA, SLC2A3 \\
\hline
\end{tabular}

TR/RXR, thyroid hormone receptor/retinoid $X$ receptor.

BioSpherix (Lacona, NY). Constant oxygen levels were maintained in the hypoxia chamber throughout the experimental procedure and incubations. All plastic ware, pipette aids, tissue culture media, and buffers were equilibrated in the hypoxic conditions before use.

\section{Incubations}

Under an institutional review board-approved human experimentation protocol, fetal adrenal tissues was transported in a full tube of
Table 6. Sequence of primers used for qRT-PCR

\begin{tabular}{|c|c|c|}
\hline Name & Sequence & $\begin{array}{l}\text { Size of } \\
\text { product } \\
\text { (bp) }\end{array}$ \\
\hline CYP11A1 forward & 5'-TCC AGA AGT ATG GCC CGATT -3' & 75 \\
\hline CYP11A1 reverse & $5^{\prime}$ - CAT CTT CAG GGT CGATGA CAT AAA - $3^{\prime}$ & \\
\hline CYP17A1 forward & 5'-TCT CTG GGC GGC CTC AA-3' & 63 \\
\hline CYP17A1 reverse & 5'- AGG CGATAC CCT TAC GGTTGT - $3^{\prime}$ & \\
\hline HSD3B2 forward & $5^{\prime}$ - GGA AGA GAA GGA ACT GAA GGA G - $3^{\prime}$ & 194 \\
\hline HSD3B2 reverse & $5^{\prime}$ - AGA CAT CAATGA TAC AGG CGG -3' & \\
\hline StAR forward & $5^{\prime}$ - CCA CCC CTA GCA CGT GGAT -3' & 88 \\
\hline StAR reverse & $5^{\prime}$-TCCTGGTCA CTGTAG AGA GTCTCTTC-3' & \\
\hline GAPDH forward & 5'- CGG GGCTCT CCA GAA CAT CAT CC -3' & 199 \\
\hline GAPDH reverse & 5'- CGA CGC CTG CTT CAC CAC CTT CTT -3' & \\
\hline ACTIN forward & 5'- AACTCCATCATGAAGTGTGACG - $3^{\prime}$ & 234 \\
\hline ACTIN reverse & 5'-GATCCACATCTGCTGGAAGG -3' & \\
\hline
\end{tabular}

qRT-PCR, quantitative reverse transcription PCR.

phosphate-buffered saline that had been degassed so as to minimize exposure to oxygen before arriving in the laboratory. All manipulations were done under hypoxic conditions. Fetal adrenals were deencapsulated, the two adrenals were combined, minced into small pieces, rinsed twice with $\mathrm{Ca} / \mathrm{Mg}$-free Hank's balanced salt solution, digested with $44 \mathrm{mg}$ dispase (Life Technologies, Carlsbad, CA), $20 \mathrm{mg}$ collagenase type I (Worthington Biochemical, Lakewood, NJ) at $37^{\circ} \mathrm{C}$ for $40 \mathrm{~min}$, filtered through $100 \mu \mathrm{m}$ nylon mesh, layered onto $5 \mathrm{ml}$ ficoll-paque plus (GE Healthcare, Piscataway, NJ), and centrifuged at $600 \mathrm{~g}$ for $30 \mathrm{~min}$ at room temperature on an IEC centraGP8R centrifuge (Thermo Fisher Scientific, Waltham, MA). The cells from the resulting interphase was collected and washed, resuspended in RPMI medium, and incubated in the hypoxic environment. Cells from each fetus were incubated separately in duplicate cultures grown in hypoxic or normoxic conditions; subsequent RNA preparations and analyses were done separately.

NCI-H295A cells were incubated under hypoxic conditions for 15 $\mathrm{d}$ and were split twice before the start of the experiment. After $15 \mathrm{~d}$, six $10-\mathrm{cm}$ plates of cells were moved from hypoxic conditions to an incubator with room air (normoxia). RNA was isolated from three plates after $1 \mathrm{~d}$ in normoxia and from the other three plates after $2 \mathrm{~d}$ in normoxia. RNA was also isolated from three control plates maintained in hypoxia.

\section{RNA Analysis}

Total RNA was isolated using TRIzol (Life Technologies) according to the manufacturer's recommended protocol. For cells kept in hypoxia, homogenization with TRIzol was done under hypoxic conditions. RNA was quantitated using an ND-1000 NanoDrop spectrophotometer (Thermo Scientific).

For real-time quantitative reverse transcription-PCR, $1 \mu \mathrm{g}$ total RNA was reverse transcribed using Superscript II reverse transcriptase (Life Technologies), and PCR was performed at $94{ }^{\circ} \mathrm{C}$ for $5 \mathrm{~min}$, followed by 40 cycles of $94{ }^{\circ} \mathrm{C}$ for $0.5 \mathrm{~min}, 55^{\circ} \mathrm{C}$ for $0.5 \mathrm{~min}$, and $72{ }^{\circ} \mathrm{C}$ for 1 min using primers and probes for the cholesterol sidechain cleavage enzyme (P450scc, encoded by CYP11A1), P450c17, 3ßHSD2, StAR, glyceraldehyde-3-phosphate dehydrogenase, and actin (Table 6). Reactions were performed in a total volume $25 \mu \mathrm{l} \mathrm{con-}$ taining $2 \mu \mathrm{l}$ complementary DNA and $12.5 \mu \mathrm{l}$ FastStart SYBR Green Master (Roche, Mannheim, Germany) on an iCycler iQ Real Time Detection System (Bio-Rad, Hercules, CA).

For microarray experiments, $300 \mathrm{ng}$ total RNA was used to produce biotin-labeled complementary RNA using Illumina TotalPrep RNA amplification kit (Life Technologies) according to the manufacturer's recommended protocol. The biotinylated complementary 
RNA was eluted in nuclease-free water and was quantitated by NanoDrop spectrophotometer. Hybridization to the HumanHT-12 v4 BeadChip array (Illumina, San Diego, CA) was done at a complementary RNA concentration of $150 \mathrm{ng} / \mu \mathrm{l}$ in the UCSF Genomic Core Facility. The chips were scanned, and data were analyzed using Genome Studio Gene Expression Module (Illumina). Data were normalized using the "quantile" method of normalization in the software. Normalized data containing the signal levels and detection $P$ values were exported into Microsoft Excel for gene expression analysis. The fold changes in gene expression levels were calculated as the gene signal levels under normoxic conditions divided by the signal levels under hypoxic conditions for control cells. The data are expressed as mean fold change in normoxia over control in hypoxia \pm SD. Genes with signal detection of $P>0.05$ in both normoxia and control groups were excluded from further analysis. An arbitrary fold change cutoff of $>1.5$-fold or $<0.67$-fold over control was chosen.

\section{SUPPLEMENTARY MATERIAL}

Supplementary material is linked to the online version of the paper at http:// www.nature.com/pr

\section{ACKNOWLEDGMENTS}

We thank Emin Maltepe for productive discussions and for the use of the hypoxia chamber, Marcus Schoneman for helpful advice, and the staff and faculty at San Francisco General Hospital Women's Options Center for assistance in the collection of human fetal tissues. V.A. is currently Assistant Professor, Centre for Microbial Biotechnology, Panjab University, Chandigarh, India.

\section{STATEMENT OF FINANCIAL SUPPORT}

This work was supported by the University of California-San Francisco Molecular Endocrinology Fund; J.Q. was supported by the School of Medicine, Shanghai Jiao Tong University, Shanghai, China.

Disclosure: The authors have nothing to disclose. The authors report no conflict of interest.

\section{REFERENCES}

1. Goto M, Piper Hanley K, Marcos J, et al. In humans, early cortisol biosynthesis provides a mechanism to safeguard female sexual development. J Clin Invest 2006;116:953-60.

2. Voutilainen R, Ilvesmäki V, Miettinen PJ. Low expression of $3 \beta$-hydroxy5 -ene steroid dehydrogenase gene in human fetal adrenals in vivo; adrenocorticotropin and protein kinase $\mathrm{C}$-dependent regulation in adrenocortical cultures. J Clin Endocrinol Metab 1991;72:761-7.

3. Kitada M, Kamataki T, Itahashi K, Rikihisa T, Kanakubo Y. P-450 HFLa, a form of cytochrome P-450 purified from human fetal livers, is the $16 \alpha$-hydroxylase of dehydroepiandrosterone 3-sulfate. J Biol Chem 1987;262:13534-7.

4. Miller KK, Cai J, Ripp SL, Pierce WM Jr, Rushmore TH, Prough RA. Stereo- and regioselectivity account for the diversity of dehydroepiandrosterone (DHEA) metabolites produced by liver microsomal cytochromes P450. Drug Metab Dispos 2004;32:305-13.

5. Leeder JS, Gaedigk R, Marcucci KA, et al. Variability of CYP3A7 expression in human fetal liver. J Pharmacol Exp Ther 2005;314:626-35.

6. Kari MA, Raivio KO, Stenman UH, Voutilainen R. Serum cortisol, dehydroepiandrosterone sulfate, and steroid-binding globulins in preterm neonates: effect of gestational age and dexamethasone therapy. Pediatr Res 1996;40:319-24.

7. Miller WL. Steroid hormone biosynthesis and actions in the materno-fetoplacental unit. Clin Perinatol 1998;25:799-817, v.

8. Siiteri PK, MacDonald PC. Placental estrogen biosynthesis during human pregnancy. J Clin Endocrinol Metab 1966;26:751-61.

9. MillerWL, Auchus RJ. The molecular biology, biochemistry, and physiology of human steroidogenesis and its disorders. Endocr Rev 2011;32:81-151.

10. McMahon SK, Pretorius CJ, Ungerer JP, et al. Neonatal complete generalized glucocorticoid resistance and growth hormone deficiency caused by a novel homozygous mutation in helix 12 of the ligand binding domain of the glucocorticoid receptor gene (NR3C1). J Clin Endocrinol Metab 2010;95:297-302.

11. Keene MF. Observations on the development of the human suprarenal gland. J Anat 1927;61(Pt 3):302-24.

12. Lanman JT. The fetal zone of the adrenal gland: its developmental course, comparative anatomy, and possible physiologic functions. Medicine (Baltimore) 1953;32:389-430.

13. Villee DB. The development of steroidogenesis. Am J Med 1972;53:533-44.

14. McNutt NS, Jones AL. Observations on the ultrastructure of cytodifferentiation in the human fetal adrenal cortex. Lab Invest 1970;22:513-27.

15. Spencer SJ, Mesiano S, Lee JY, Jaffe RB. Proliferation and apoptosis in the human adrenal cortex during the fetal and perinatal periods: implications for growth and remodeling. J Clin Endocrinol Metab 1999;84:1110-5.

16. Sucheston ME, Cannon MS. Development of zonular patterns in the human adrenal gland. J Morphol 1968;126:477-91.

17. Kojima S, Yanaihara T, Nakayama T. Serum steroid levels in children at birth and in early neonatal period. Am J Obstet Gynecol 1981;140:961-5.

18. Grueters A, Korth-Schutz S. Longitudinal study of plasma dehydroepiandrosterone sulfate in preterm and fullterm infants. J Clin Endocrinol Metab 1982;55:314-20.

19. Midgley PC, Russell K, Oates N, Holownia P, Shaw JC, Honour JW. Adrenal function in preterm infants: ACTH may not be the sole regulator of the fetal zone. Pediatr Res 1998;44:887-93.

20. Ben-David S, Zuckerman-Levin N, Epelman M, et al. Parturition itself is the basis for fetal adrenal involution. J Clin Endocrinol Metab 2007;92:93-7.

21. Di Blasio AM, Voutilainen R, Jaffe RB, Miller WL. Hormonal regulation of messenger ribonucleic acids for P450scc (cholesterol side-chain cleavage enzyme) and P450c17 (17 $\alpha$-hydroxylase/17,20-lyase) in cultured human fetal adrenal cells. J Clin Endocrinol Metab 1987;65:170-5.

22. Higashimura Y, Nakajima Y, Yamaji R, et al. Up-regulation of glyceraldehyde-3-phosphate dehydrogenase gene expression by HIF-1 activity depending on Sp1 in hypoxic breast cancer cells. Arch Biochem Biophys 2011;509:1-8.

23. Staels B, Hum DW, Miller WL. Regulation of steroidogenesis in NCIH295 cells: a cellular model of the human fetal adrenal. Mol Endocrinol 1993;7:423-33.

24. Halle C, Andersen E, Lando M, et al. Hypoxia-induced gene expression in chemoradioresistant cervical cancer revealed by dynamic contrastenhanced MRI. Cancer Res 2012;72:5285-95.

25. Holland RC. The effect of hypoxia on the fetal rat adrenal. Anat Rec 1958;130:177-95.

26. Myers DA, Hyatt K, Mlynarczyk M, Bird IM, Ducsay CA. Long-term hypoxia represses the expression of key genes regulating cortisol biosynthesis in the near-term ovine fetus. Am J Physiol Regul Integr Comp Physiol 2005;289:R1707-14.

27. Honour JH, Wickramaratne K, Valman HB. Adrenal function in preterm infants. Biol Neonate 1992;61:214-21.

28. Dunwoodie SL. The role of hypoxia in development of the mammalian embryo. Dev Cell 2009;17:755-73.

29. Rudolph AM. Fetal circulation and cardiovascular adjustments after birth. In: Rudolph AM, Hoffman JIE, Rudolph CD, eds. Rudolph's Pediatrics, 20th edn. Stamford, CT: Appleton \& Lange, 1996:1409-13.

30. Park AM, Sanders TA, Maltepe E. Hypoxia-inducible factor (HIF) and HIF-stabilizing agents in neonatal care. Semin Fetal Neonatal Med 2010;15:196-202.

31. Mesiano S, Mellon SH, Jaffe RB. Mitogenic action, regulation, and localization of insulin-like growth factors in the human fetal adrenal gland. J Clin Endocrinol Metab 1993;76:968-76.

32. Gazdar AF, Oie HK, Shackleton CH, et al. Establishment and characterization of a human adrenocortical carcinoma cell line that expresses multiple pathways of steroid biosynthesis. Cancer Res 1990;50:5488-96.

33. Rodriguez H, Hum DW, Staels B, Miller WL. Transcription of the human genes for cytochrome P450scc and P450c17 is regulated differently in human adrenal NCI-H295 cells than in mouse adrenal Y1 cells. J Clin Endocrinol Metab 1997;82:365-71. 